\title{
初期に高温履歴を受ける高強度セメント硬化体の強度発現性状と微細構造 STRENGTH DEVELOPMENT AND POROSITY OF HIGH STRENGTH HARDENED CEMENT SUBJECT TO HIGH TEMPERATURE HISTORY AT EARLY AGE
}

\author{
陣内 浩*, 黒岩秀介*, 早川光敬** \\ Hiroshi JINNAI, Shusuke KUROIWA and Mitsutaka HAYAKAWA
}

\begin{abstract}
The long term strength in a high strength concrete structure is known to less than that of standard cured specimens. This difference is caused by the curing temperature experienced at early age, but, the detailed mechanism of the phenomenon is unknown. In this work, the strength development and porosity of test specimens under various temperature conditions were investigated. It was found that the difference between strength in a structure and that of standard cured specimen does not increase in proportion to the decrease in the water-cement ratio. And the detailed mechanism of the phenomenon is explained by the relation between aging time and porosity of the test specimens.
\end{abstract}

Key words : High strength hardened cement, High temperature history, Strength development, porosity 高強度セメント硬化体、高温履歴、強度発現、微細構造

1.はじめに

近年、様々な技術の進歩により、単位セメント量が $500 \mathrm{~kg} / \mathrm{m}^{3}$ を 超える高強度コンクリートも容易に製造・施工することが可能とな った。このような高強度コンクリートは水和による発熱量が大きく、 夏期であれば、断面寸法 $85 \mathrm{~cm} \times 85 \mathrm{~cm}$ 程度の一般的な柱に打設した 場合でも、部材の中心温度は $80^{\circ} \mathrm{C}$ 程度まで上昇することが報告さ れている"。このような部材に打設された構造体コンクリートは、 自らの水和熱によってセメントの水和が促進され、初期材齠では管 理用供試体よりも高い強度を発現するものの、その後の水和が停滞 し、ある材龄を経過すると管理用供試体よりも低い压縮強度となる ことが周知のこととなっている に高い温度履歴を受けた構造体コンクリートは、従来より強度管理 に用いられてきた現場水中養生もしくは現場封かん盖生供試体によ って管理することができないという問題が生じる。

1997年に改定された建築工事標準仕様書 ·同解説 J A S S 5 「鉄 筋コンクリート工事」（以下、J A S S 5 と称す。）では、このよ うな高強度コンクリートの施工時に生じる現象を調合式に反映させ、 標準養生した供試体の圧縮強度と構造体コンクリート強度の差（以 下、強度補正値 Sと称す。）を用いて調合強度を定めることとなっ ている。しかし、同仕様書に扔いてもここで用いる強度補正値 $\mathrm{S}$ を
定量化するには至っておらず、実績のない高強度コンクリートを製 造する場合には柱構造体モデルの構造体コンクリート強度を調査す ることなどによって強度補正值 Sの值を設定しなければならない。

このような初期に高い温度履歴を受けたセメント硬化体の性状に ついては、すでに多くの研究者によって報告され3〉-9)、異なる養 生温度のもとでは、組織の異なる水和物ができることなどが明らか になっている。しかしながら、現状でも強度補正値 $\mathrm{S}$ の発生理論は 必ずしも明確でなく、初期に高い温度履歴を受けた構造体コンクリ 一トの強度発現性状を理論的に求めるのは困難である。

そこで筆者らは、強度補正值 Sの定量化を目的とした基礎研究と して、初期に高い温度履歴を受けたセメント硬化体が標準養生した セメント硬化体の圧縮強度を下回る場合の要因と理由を検討した。

実験では、まず初期の養生温度と水セメント比を実験因子とする セメントペースト実験を行い、これらの因子がセメントペーストの 強度発現に与える影響を把握することとした。また、初期養生温度 の異なるセメントペーストが異った強度発現となる理由を明らかに するため、材㱓経過による細孔分布および強熱減量の変化を調べる こととした。さらに、セメントペーストの強度発現性状から構造体 コンクリートの強度発現性状を推定する基礎的な検討を行うため、 コンクリートの構造体モデルを用いた実大実験を実施した。 


\section{2. 室内実験}

\section{1 目的と実験概要}

室内実験の目的は、初期に高い温度履歴を受けたセメント硬化体 の圧縮強度が、長期材㱓において標準養生したセメント硬化体の圧 縮強度を下回るという現象を、セメントペーストの強度発現性状か ら検討することである。また、養生条件の異なるセメントペースト の強度発現性状を硬化体の微細構造から明らかにするため、材齢経 過によるセメントペーストの細孔分布および強熱隇量の変化を調べ ることとした。

\section{2 実験計画}

\subsection{1 因子と水準}

実験因子と水準を表 1 に示す。実験因子は、水セメント比と盖生 条件である。水セメント比は $20 \% 、 30 \%$ よび $40 \%$ の 3 水準を設 定した。養生条件は、標準養生 $\left(20^{\circ} \mathrm{C}\right.$ 水中養生）と設定した温度 履歴にプログラム運転できる恒温恒湿器を用いた 3 種類の加熱養生 である。基本となる $20^{\circ} \mathrm{C}$ の養生を水中養生としたのは、構造体コ ンクリート強度を標準養生した供試体の圧縮強度によって管理する J A S S 5 の手法にあわせたためである。

表 1 因子と水準

\begin{tabular}{|c|c|}
\hline 水セメント比（\%) & 養生条件 \\
\hline $\begin{array}{l}20 \text { (加熱開始: 4時間00分) } \\
30 \text { (加熱開始: 3時間30分) } \\
40 \text { (加熱開始: 0時間 } 30 \text { 分) }\end{array}$ & $\begin{array}{l}\text { 標準養生 } \\
\text { 加熱養生 }\left(\max 35^{\circ} \mathrm{C}\right) \\
\text { 加熱養生 }\left(\max 50^{\circ} \mathrm{C}\right) \\
\text { 加熱養生 }\left(\max 85^{\circ} \mathrm{C}\right)\end{array}$ \\
\hline
\end{tabular}

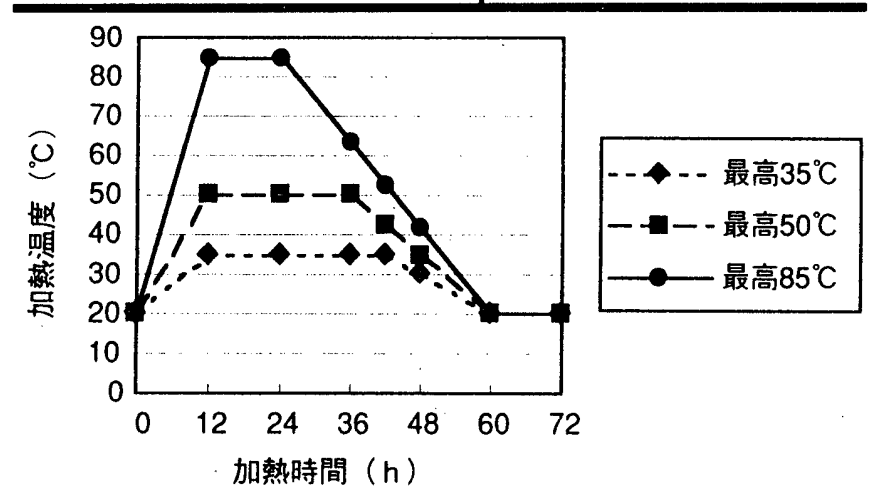

図 1 加熱養生の温度履歴

表 2 普通ポルトランドセメント（メーカーの試験成績による）

\begin{tabular}{|c|c|c|c|c|c|c|c|c|}
\hline \multirow[b]{2}{*}{$\begin{array}{l}\text { 密度 } \\
\mathrm{g} / \mathrm{cm}^{3}\end{array}$} & \multirow{2}{*}{$\begin{array}{l}\text { 比表 } \\
\text { 面積 } \\
\mathrm{cm}^{2} / \mathrm{g}\end{array}$} & \multicolumn{2}{|c|}{ 凝結 } & \multicolumn{3}{|c|}{ 圧縮強さ $\mathrm{N} / \mathrm{mm}^{2}$} & \multirow{2}{*}{$\begin{array}{c}\mathrm{MgO} \\
\%\end{array}$} & \multirow{2}{*}{$\begin{array}{c}\mathrm{SO}_{3} \\
\%\end{array}$} \\
\hline & & $\begin{array}{c}\text { 始発 } \\
\text { h-min }\end{array}$ & 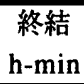 & 3日 & 7 日 & 28日 & & \\
\hline 3.16 & 3300 & $2-24$ & $3-35$ & 29.1 & 43.9 & 61.2 & 1.45 & 2.00 \\
\hline
\end{tabular}

表 3 練混ぜ時のセメントペーストの性状

\begin{tabular}{|c|c|c|c|c|c|c|c|c|c|}
\hline \multirow{2}{*}{$\begin{array}{c}\mathrm{W} / \mathrm{C} \\
\%\end{array}$} & \multirow{2}{*}{$\begin{array}{l}\text { 混和 } \\
\text { 剤量 } \\
\mathrm{C} \times \%\end{array}$} & \multicolumn{3}{|c|}{$\begin{array}{c}\text { フロー值（平均値） } \\
(\mathrm{mm})\end{array}$} & \multicolumn{2}{|c|}{\begin{tabular}{|c|}
$\begin{array}{c}\text { 単位容積質量 } \\
(\mathrm{kg} / \mathrm{l} \text { 州 })\end{array}$ \\
\end{tabular}} & \multicolumn{2}{|c|}{$\begin{array}{c}\wedge^{\circ}-\text {-x温度 } \\
\left({ }^{\circ} \mathrm{C}\right)\end{array}$} & \multirow{2}{*}{$\begin{array}{c}\text { 空気 } \\
\text { 量 }^{*} \\
\%\end{array}$} \\
\hline & & $1 ハ^{*} \%$ & 2 バッf & 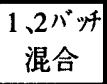 & 1 バッ & 2 バッ & 1 1バッf & 2 ハバッf & \\
\hline 20 & 1.28 & 208 & 221 & 208 & 2.292 & 2.287 & 30.1 & 31.8 & 0.6 \\
\hline 30 & 0.42 & 230 & 277 & 247 & 2.111 & 2.125 & 23.5 & 24.1 & 0 \\
\hline 40 & 0.15 & 209 & 245 & 221 & 1.980 & 1.950 & 23.0 & 22.6 & 0 \\
\hline
\end{tabular}

*空気量は $1 、 2 ハ ゙$ 状の単位容積質量の平均值と材料の密度から求めた。
加熱養生供試体に与える温度履歴を図 1 に示す。温度履歴の最高

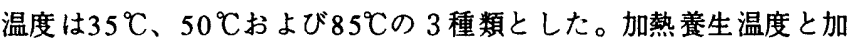
熱時間の関係は、文献 1）のような実大実験における柱構造体モデ ルの内部温度を参考に定めた。加熱盖生供試体は、図 1 の温度履歴 を与えた後、 $20^{\circ} \mathrm{C}$ 封かん養生とした。供試体に温度履歴を与えは じめる時間は、あらかじめ同じ調合のセメントペーストについて注 水から水和発熱開始までの時間を測定し、この時間にあわせた。

\subsection{2 使用材料}

使用したセメントの物理的性質を表 2 に示す。使用したセメント はすべて普通ポルトランドセメントである。化学混和剂としては、 ポリカルボン酸系高性能 A E 減水剤を使用した。

\subsection{3 試験項目}

試験項目は、压縮強度試験、強熱減量測定および細孔分布測定と した。圧縮強度試験は、 $\phi 5 \times 10 \mathrm{~cm}$ 供試体を用いて実施した。強熱 減量測定および細孔分布測定用にも $\phi 5 \times 10 \mathrm{~cm}$ 供試体を作製し、こ れを $7 \times 7 \times 7 \mathrm{~mm}$ の立方体に切断して測定試料とした。強熱減量お よび細孔分布測定用の測定試料の前処理方法としては、アセトンを 用いてセメントの水和を停止し、さらにD-乾燥によって残った余
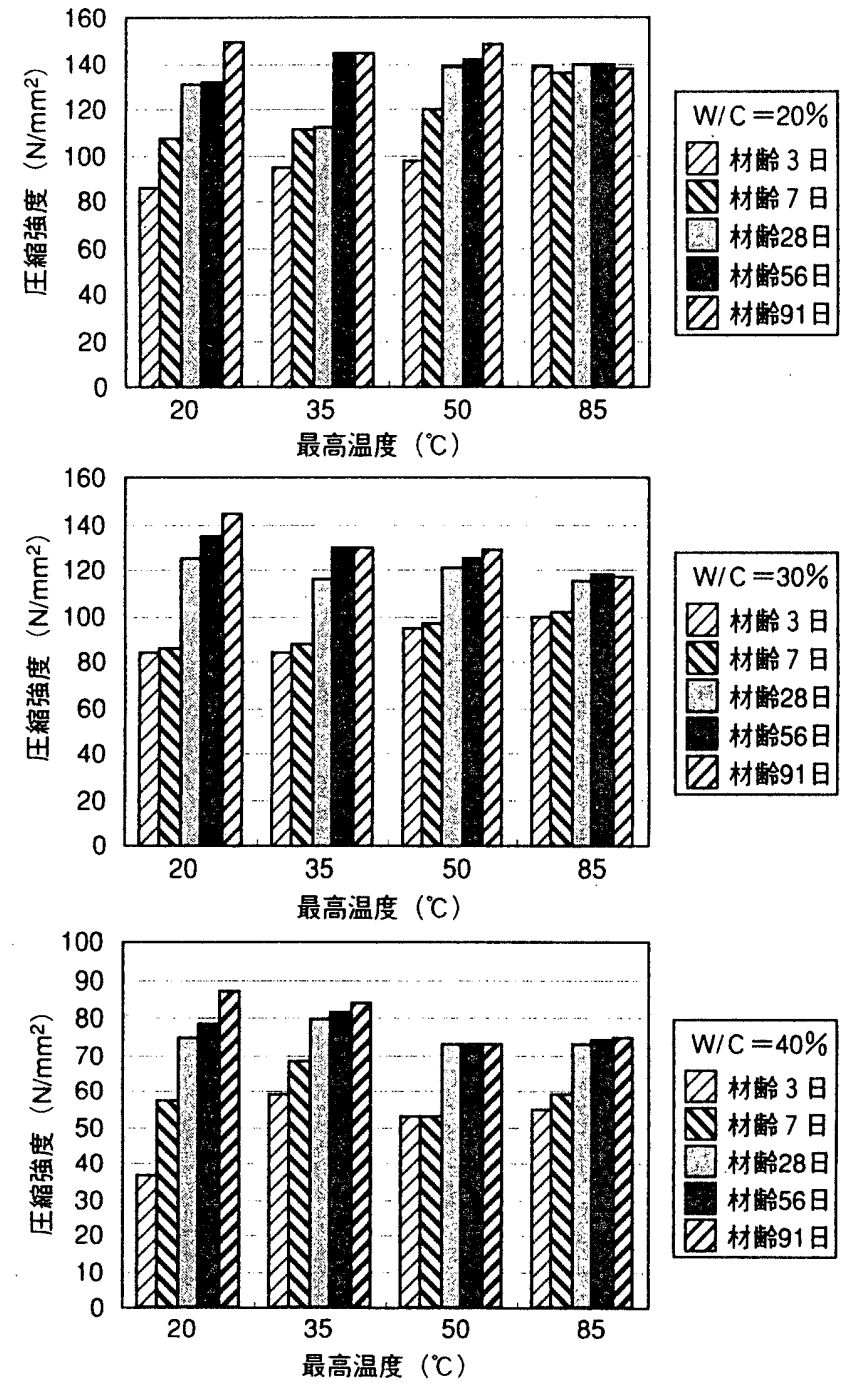

図 2 養生温度と圧縮強度の関係 
剩水を除去する手法とした。

強熱減量の值は、測定試料を電気炉 $\left(1000^{\circ} \mathrm{C}\right)$ で恒量になるま で熱し、加熱前後の質量を測定することで求めた。測定した強熱減 量の中には結合水以外にセメント自身の微量な強熱減量が含まれる が、本論ではこれを無視し、強熱減量の増加はセメントの水和の進 行とほほ等しいものと考えた。細孔分布の測定は、水銀圧入方式の ポロシメータを用いて行った。

\subsection{4 練混ぜ}

練混ぜには30リットルのホバート型ミキサを使用した。供試体 作製に必要なセメントペーストの量は30リットルであったため、 15 リットルを 2 回練混ぜ、これを混ぜ合わせて使用した。練混ぜ
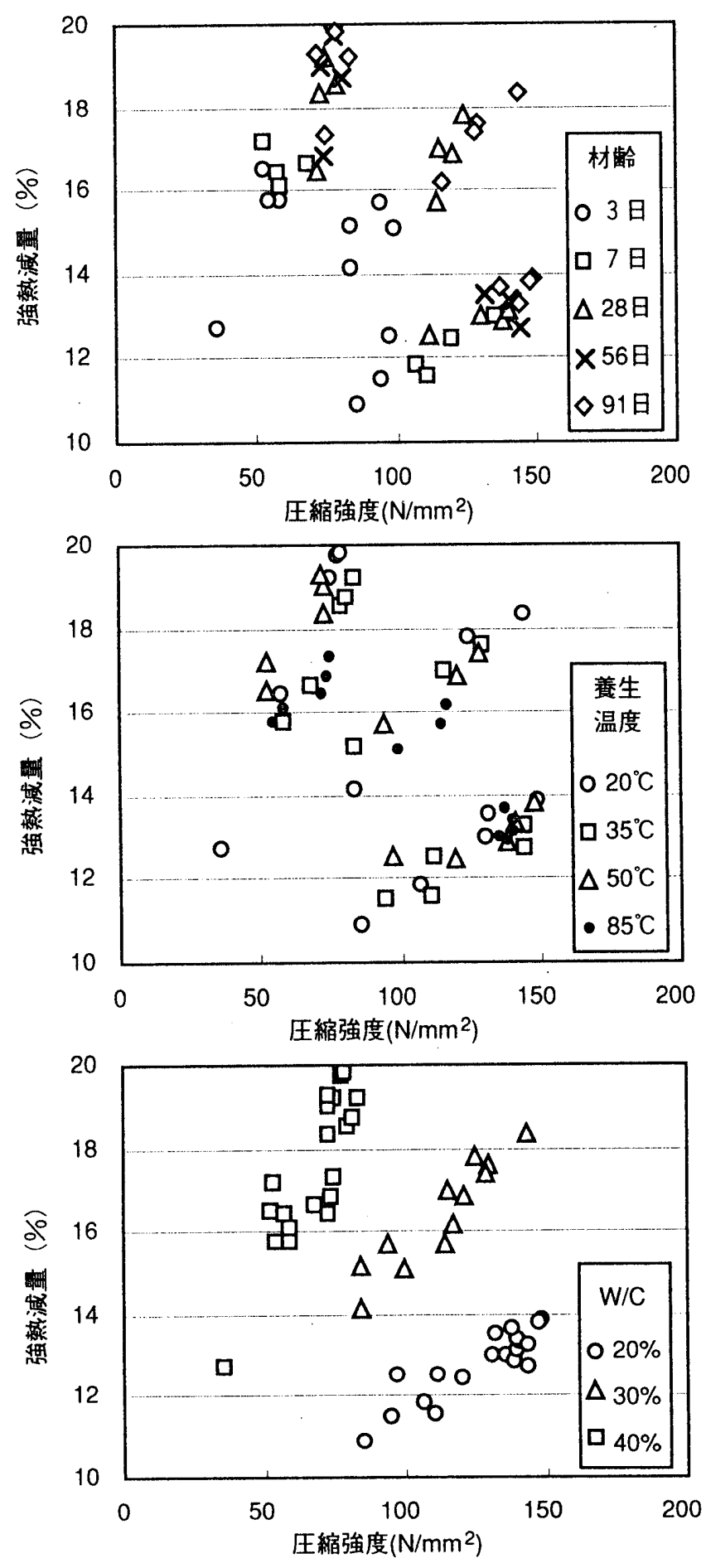

図 3 圧縮強度試験結果と強熱減量の関係
時間は水セメント比 $20 \%$ $\%$ もを注水から 4 分間、 $30 \%$ よび 40 \%のものを注水から 3 分間とした。フロー試験はJIS R 5201「セメ ントの物理試験方法」に準拠したが、流動性が高いため、無振動で フロー值を測定した。目標フロー值は、セメントの分散および供試 体成形を考慮して $200 \mathrm{~mm}$ 以上とした。練混ぜ時のセメントペース トの性状は表 3 に示すものであった。

\section{3 実験結果}

\subsection{1 圧縮強度}

圧縮強度試験結果を図 2 に示す。いずれの水セメント比において も、初期により高い温度履歴を受けたものほど、材㱓 3 日での初期 強度の発現には有利であるが、材齢 3 日以降の強度発現が停滞する

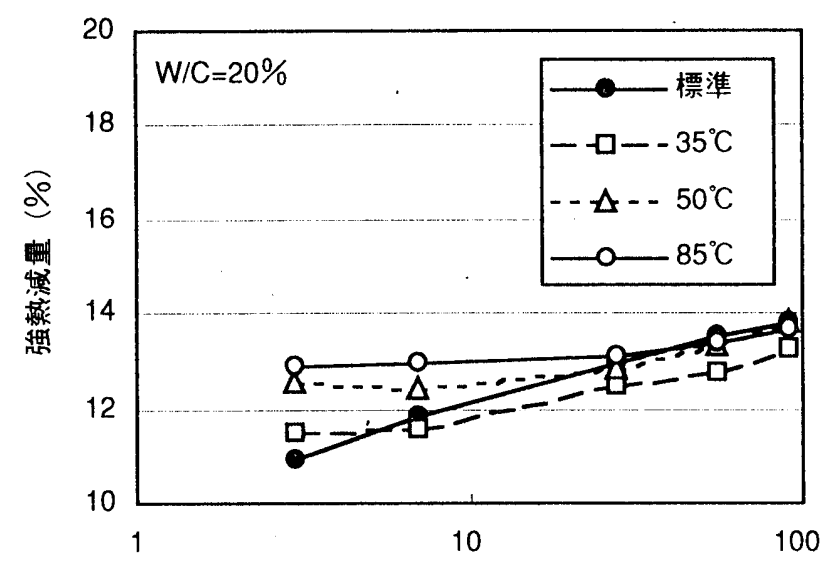

材齢（日）

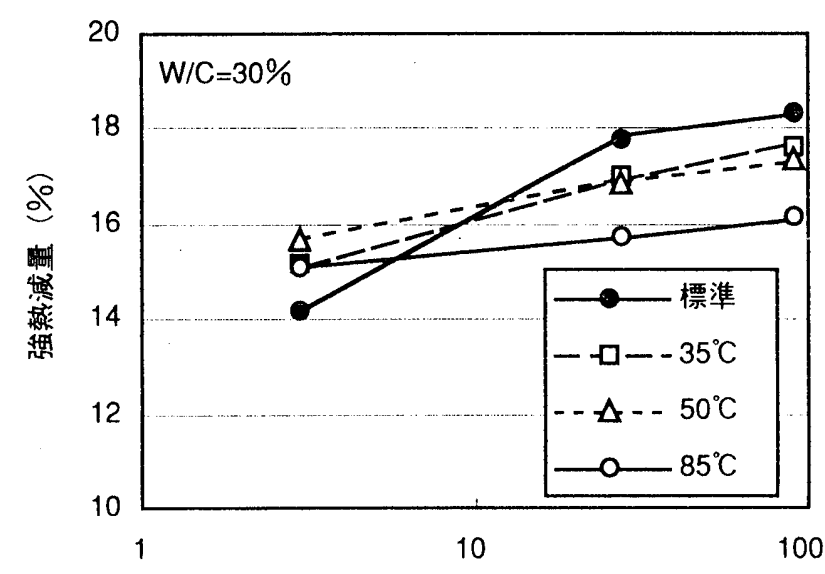

材歯（日）

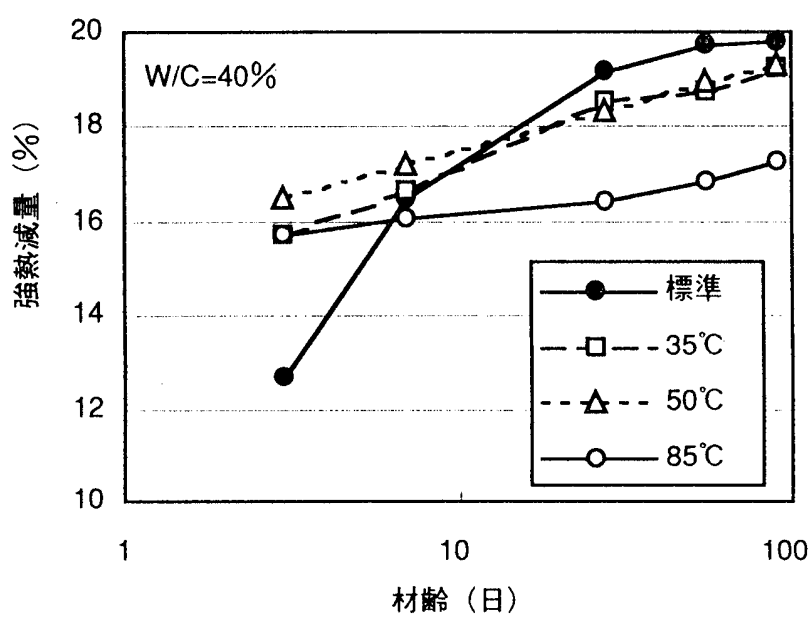

図 4 材龄と強熱減量の関係 
傾向がある。このような傾向は既往の報告 ${ }^{2)}$ とも致している。

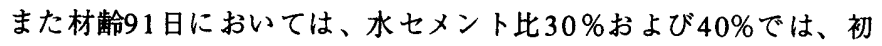
期により高い温度履歴を受けた供試体ほど低い圧縮強度を示す傾向 がみられたが、水セメント比 $20 \%$ では、盖生条件による圧縮強度 の違いがあまりみられなかった。

\subsection{2 強熱減量}

圧縮強度試験結果と強熱減量の関係を図 3 に示す。これより、同 一水セメント比という条件であれば、圧縮強度と強熱減量の間には 概ね相関があり、強熱隇量が大きいセメントペーストほど、高い圧 縮強度を発現することがわかる。

材齢と強熱減量の関係を図 4 に示す。いずれの水セメント比にお
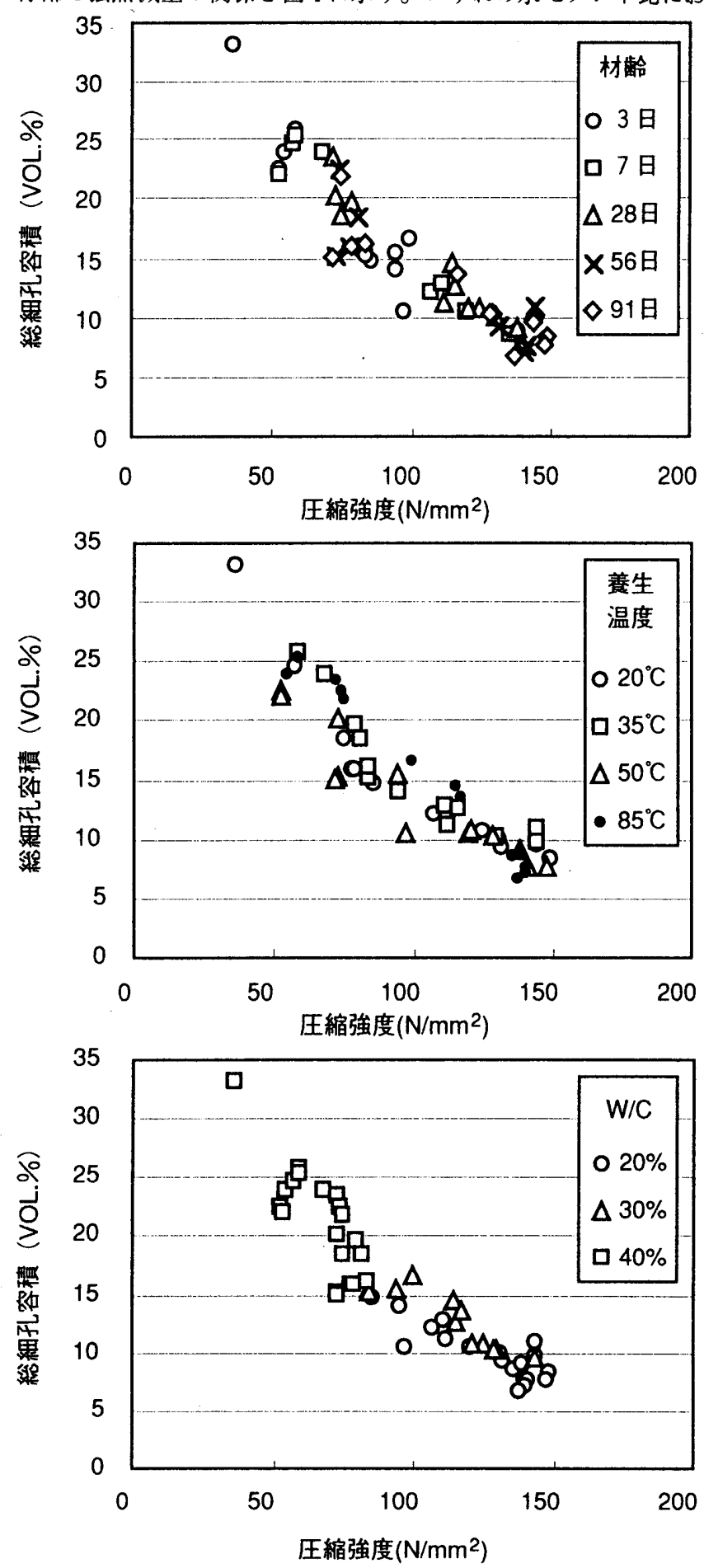

図 5 圧縮強度と総細孔容積の関係
いても、標準盖生したセメントペーストの強熱隇量は、材齡 3 日で は他に比べて最も小さいものの、材軨 3 日以降の増加量が大きく、 材齡91日までには最も大きくなることがわかる。また、このよう な傾向は水セメント比 $40 \%$ において最も顕著であり、水セメント 比が低くなるほど養生条件の差も小さくなった。

\subsection{3 細孔分布}

材秢と $32 \sim 0.0032 \mu \mathrm{m}$ の総細孔容積の関係を図 5 に示す。これ より、圧縮強度と 32 0.0032 $\mu \mathrm{m}$ の総細孔容積の間には、概ね相 関があることがわかる。また、今回の実験結果では、材龄や養生条 件が、圧縮強度と総細孔容積の関係に明らかな影響を及ほすように はみえない。養生条件と細孔容積の関係を図6に示す。これより、
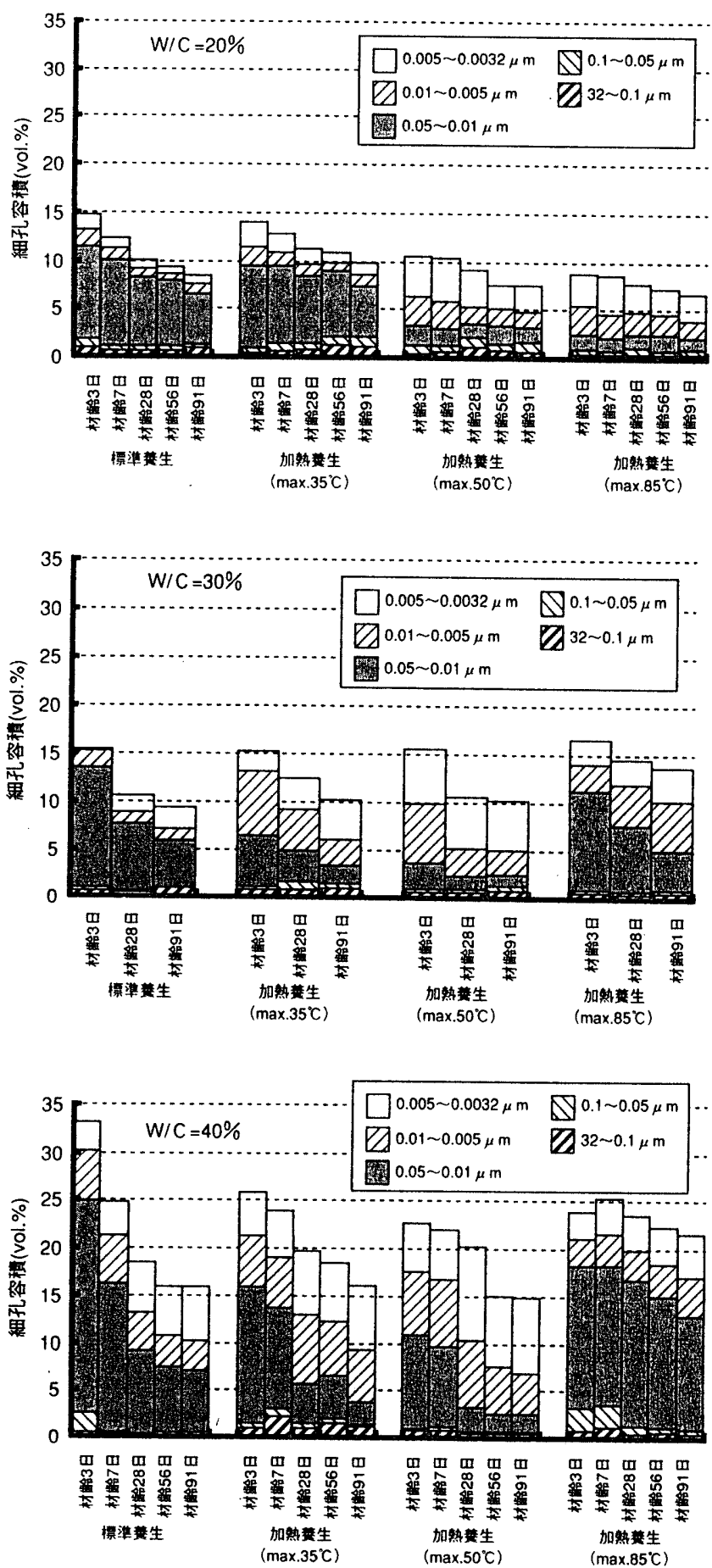

図 6 養生条件と細孔容積の関係 
いずれの養生条件であっても材齢の経過とともに総細孔容積は小さ くなるが、水セメント比が小さくなるほど、細孔が減少する速度は 緩慢になることがわかる。

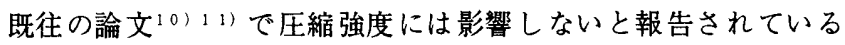
微細な細孔（ここでは直径 $0.01 \mu \mathrm{m}$ 未満とする。）の細孔容積を 総細孔容積から除いて考えれば、いずれの水セメント比においても、 標準養生したセメントペーストは他に比べて材龄 3 日での総細孔容 積が最も大きいが、材齢 3 日以降での総細孔容積の減少は最も速い ことがわかる。さらに、最高 $85^{\circ} \mathrm{C}$ の温度履歴を与えたセメントペ 一ストは、水セメント比 $30 \%$ および $40 \%$ では材龄91日までに他に 比べて総細孔容積が最も大きなものとなっているが、水セメント比 $20 \%$ では、いずれの材齢でも他に比べて総細孔容積が最も小さく なっていることがわかる。

細孔直径と $32 \sim 0.0032 \mu \mathrm{m}$ の積算細孔容積の関係を図 7 に、細 孔直径と細孔容積の関係を図 8 に示す。これらより、いずれの養生 条件のセメントペーストの微細構造も、様々な径の細孔が均等に形 成されているわけではなく、ある径の細孔容積が卓越していること がわかる。図 7 と図 8 を比較すると、総細孔容積の減少は主にこの 卓越した細孔径の容積が減少することによって生じることがわかる。
また、同一水セメント比であれば、標準養生した場合に卓越してい る細孔の径は大きく、その容積も大きくなる傾向がみられる。標準 養生したセメントペーストの総細孔容積の減少が、他に比べて速く なる理由は、このような埋めやすい大きな細孔を多く保有する微細 構造であることに起因すると考える。さらに、同じ養生を行ったセ メントペーストであっても、水セメント比が低くなるにつれて卓越 した細孔径が小さな径に推移し、その容積も小さくなることがわか る。水セメント比が小さくなるほど総細孔容積の減少が緩慢になる 理由は、微細構造がこのような水和物の埋めにくい細かい細孔で形 成されたものに推移するためであると考える。

\section{4 室内実験のまとめ}

圧緍強度試験の結果より、初期に高い温度履歴を受けたセメント ペーストの圧縮強度は、初期材齢では標準養生したものよりも高い 強度を発現するものの、その後の水和が停滞し、ある材龄を経過す ると標準養生したものよりも低くなる傾向があることが再確認でき た。また、水セメント比が40\%の場合には、初期により高い温度 履歴を受けたセメントペーストほど標準盖生したものよりも材踚 91 日での圧紡強度が低くなる傾向が見られたが、水セメント比が 低くなるにつれてその差は小さくなる傾向にあった。この傾向は、
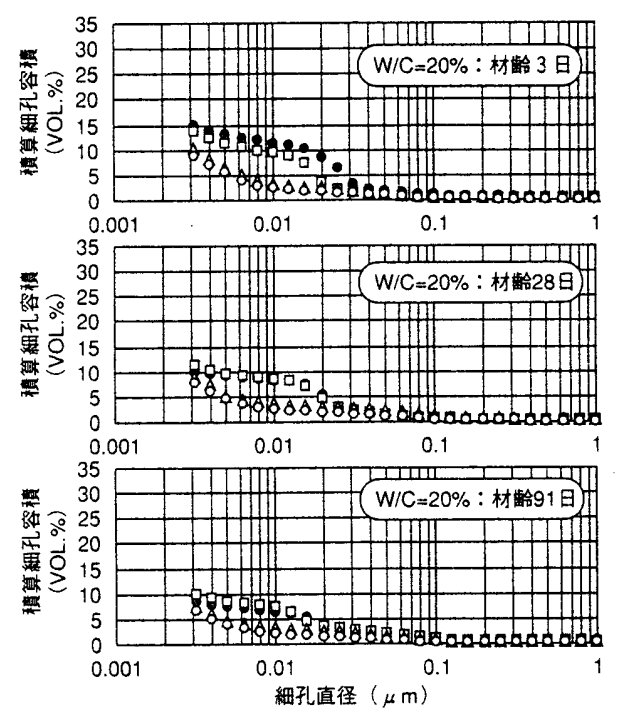

細孔直径 $(\mu \mathrm{m})$
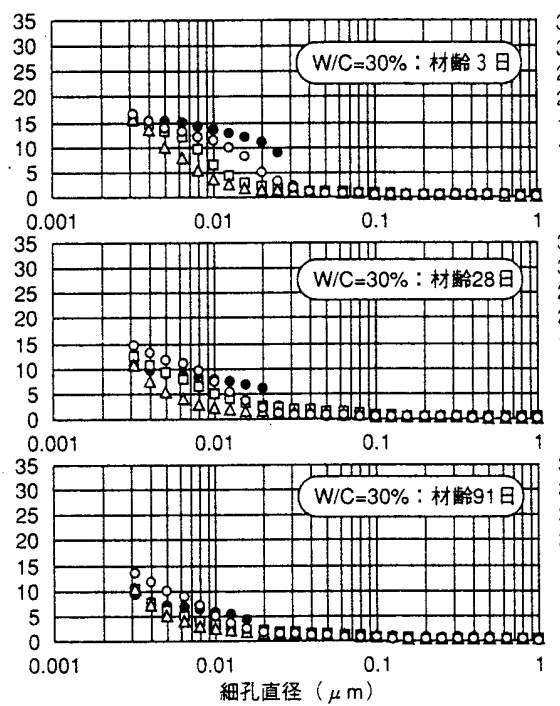

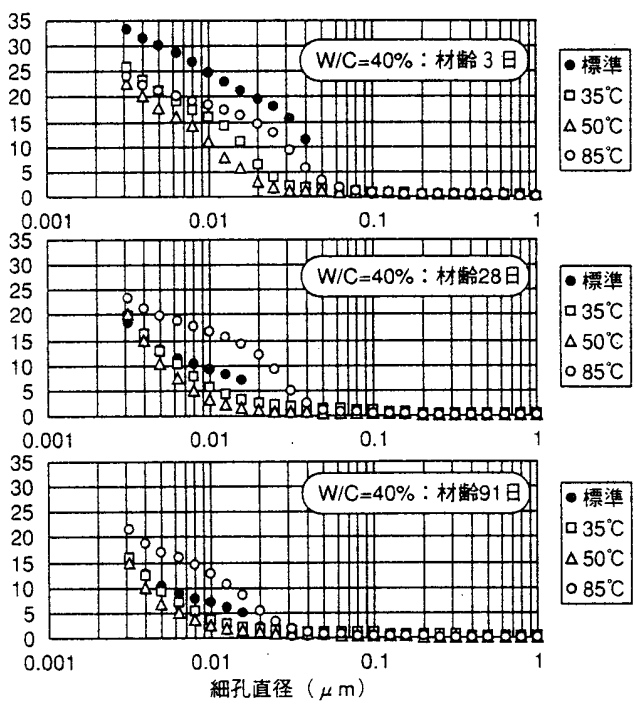

図 7 細孔直径と積算細孔容積 $(32 \sim 0.0032 \mu \mathrm{m})$ の関係
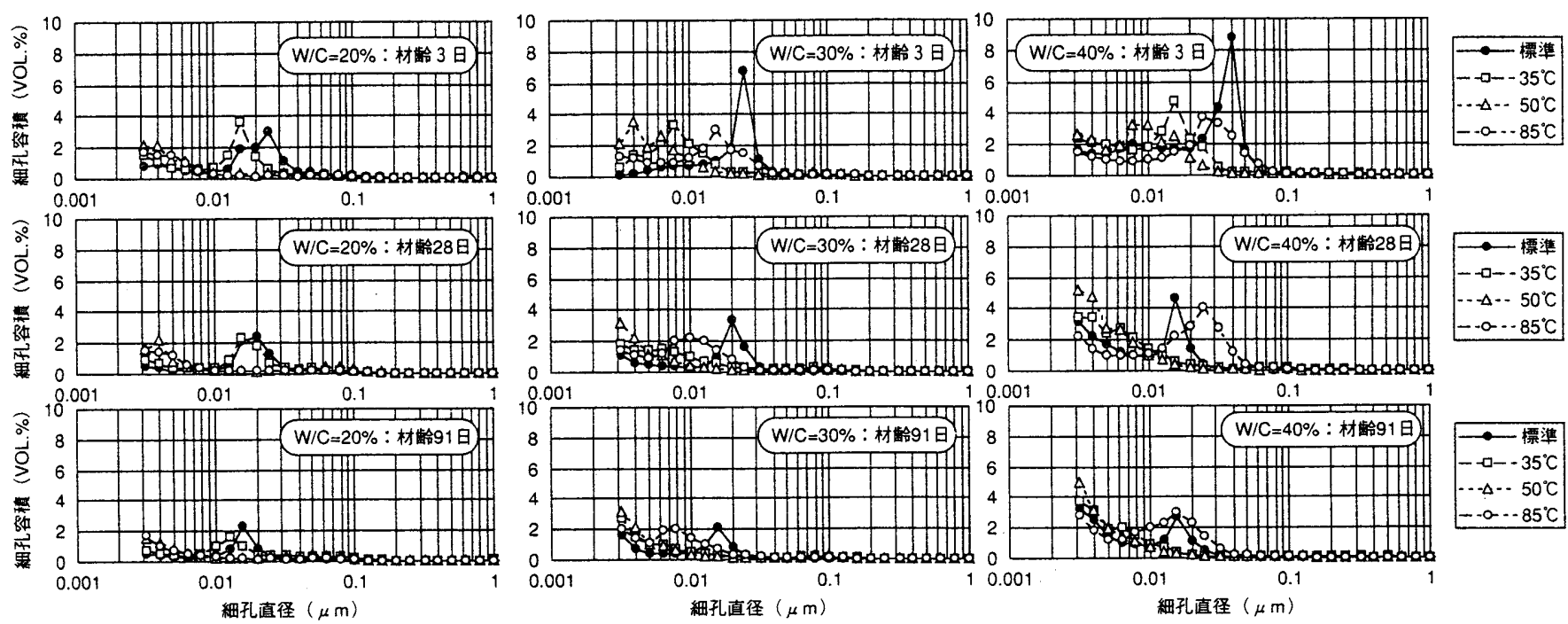

図 8 細孔直径と 細孔容積の関係 


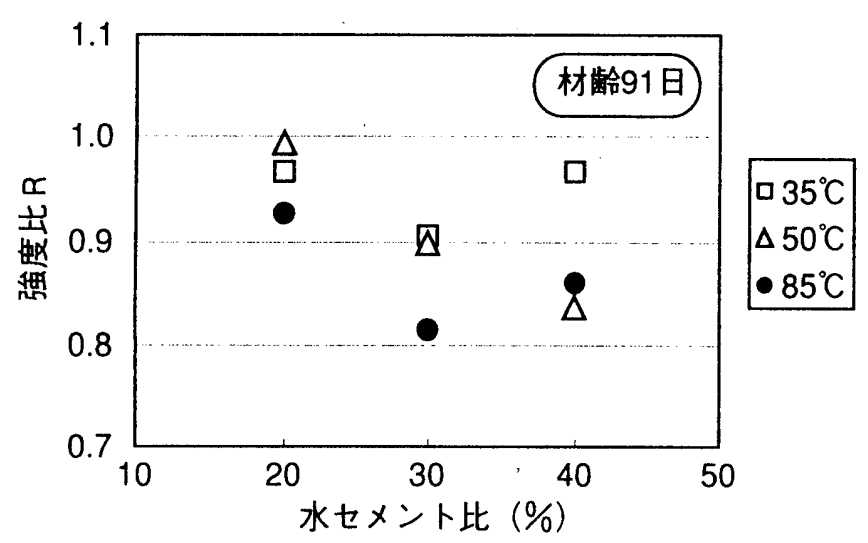

図 9 材齢91日における水セメント比と強度比 $\mathrm{R}$ の関係

既往の報告”とも一致しており、今回の実験では、強熱減量によっ て示される水和の進行にも表づけられるものであった。また、初期 に高い温度履歴を受けたセメントペーストの圧縮強度の発現が標準 養生したものよりも停滞する理由や、水セメント此が低くなるにつ れて初期温度の影響が小さくなる理由は、細孔構造によって説明で きるものであった。

次に、実験結果の整理にあたり、本論では初期に高い温度履歴を 受けた供試体の圧縮強度を標準養生した供試体の圧縮強度で除した 値を強度比 $\mathrm{R}$ と定義する。材㱓91日における水七メント比と強度 比 Rの関係を図 9 に示す。これより、材舲91日における強度比 $\mathrm{R}$ は、水セメン、比 $30 \%$ 40\%程度では初期により高い温度履歴を 受けたものほど小さく、0.8程度となる場合もあるが、水セメント 比が $20 \%$ 程度まで低くなると、いずれの養生条件でも0.9を超えた 値となることがわかる。

\section{3. 実大実験}

\section{1 実験概要と目的}

実大実験の目的は、打設時期と水セメント比を実験要因とした構 造体コンクリートの強度発現性状を把握し、セメントペースト実験 で得られた結果との相関性を検討することである。そこで、夏期と 冬期に水セメント比 $21 \sim 45 \%$ 範囲のコンクリートを製造し、標 準養生した供試体の圧縮強度と柱構造体モデルのコア強度を比較す ることとした。

\section{2 実験計画}

\subsection{1 使用材料}

使用したセメントの物理的性質を表 4 に示す。使用したセメント はすべて普通ポルトランドセメントであり、銘柄は室内実験と同じ ものを採用している。使用した骨材の物理的性質を表 5 に示す。選 定した骨材の組み合わせは、最も低水セメント比のコンクリートに おいて、フレッシュコンクリートが良好な施工性を保持し、かつ骨 材の強度によってコンクリートの圧縮強度が頭打ちとならない組み 合わせとした。化学混和郕としては、ポリカルボン酸系高性能 $\mathrm{AE}$ 隇水歳を使用した。

\section{2 .2 調合}

コンクリートの調合を表 6 に示す。水セメント比は $21 \% 、 30 \%$ 、 $40 \%$ および $45 \%$ \% 4 種類とした。いずれの調合も、単位水量は $175 \mathrm{~kg} / \mathrm{m}^{3}$ 、空気量は $3 \%$ とした。また、本実験では水セメント比
表 4 普通ポルトランドセメント（メーカーの試験成績による）

\begin{tabular}{|c|c|c|c|c|c|c|c|c|c|}
\hline & \multirow[b]{2}{*}{$\begin{array}{l}\text { 密度 } \\
\mathrm{g} / \mathrm{cm}\end{array}$} & \multirow{2}{*}{$\begin{array}{l}\text { 比表 } \\
\text { 面積 } \\
\mathrm{cm}^{2} / \mathrm{g}\end{array}$} & \multicolumn{2}{|c|}{ 凝結 } & \multicolumn{3}{|c|}{ 压縮強さ $\mathrm{N} / \mathrm{mm}^{2}$} & \multirow[b]{2}{*}{$\begin{array}{c}\mathrm{MgO} \\
\%\end{array}$} & \multirow[b]{2}{*}{$\begin{array}{c}\text { SO3 } \\
\%\end{array}$} \\
\hline & & & 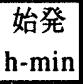 & 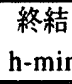 & 3日 & 7日 & 28日 & & \\
\hline 夏期 & 3.16 & 3300 & $2-21$ & $3-30$ & 29.7 & 43.6 & 61.8 & 1.42 & 2.01 \\
\hline \multirow[t]{3}{*}{ 冬期 } & 3.16 & 3320 & $2-23$ & $3-35$ & 29.4 & 44.1 & 60.8 & 1.40 & 2.00 \\
\hline & \multicolumn{9}{|c|}{ 表 5 骨 材 } \\
\hline & & & \multicolumn{2}{|c|}{$\begin{array}{c}\text { 絶乾密度 } \\
\mathrm{g} / \mathrm{cm}^{2}\end{array}$} & $\begin{array}{c}\text { 吸水率 } \\
\%\end{array}$ & \multicolumn{2}{|c|}{$\begin{array}{c}\text { 粒形判定 } \\
\text { 実積率 } \\
\%\end{array}$} & \multicolumn{2}{|c|}{ 粗粒率 } \\
\hline \multirow{2}{*}{\multicolumn{2}{|c|}{$\begin{array}{c}\text { 安山岩系 } \\
\text { 砕石 }\end{array}$}} & 夏期 & \multicolumn{2}{|c|}{2.59} & 2.05 & & 59.6 & \multicolumn{2}{|c|}{6.71} \\
\hline & & 冬期 & \multicolumn{2}{|c|}{2.59} & 2.01 & & 59.5 & \multicolumn{2}{|c|}{6.70} \\
\hline \multirow{2}{*}{\multicolumn{2}{|c|}{ 山砂 }} & 夏期 & \multicolumn{2}{|c|}{2.57} & 1.74 & & - & \multicolumn{2}{|c|}{2.71} \\
\hline & & 冬期 & \multicolumn{2}{|c|}{2.57} & 1.78 & & - & \multicolumn{2}{|c|}{2.73} \\
\hline
\end{tabular}

表 6 コンクリートの調合

\begin{tabular}{|c|c|c|c|c|c|c|c|c|}
\hline \multirow{3}{*}{$\begin{array}{c}\text { W/C } \\
\%\end{array}$} & \multirow{3}{*}{$\begin{array}{c}\text { 目標 } \\
\text { 空気量 } \\
\%\end{array}$} & \multirow{3}{*}{$\begin{array}{c}\text { 目標 } \\
\text { スランプ 7ロ- } \\
\text { c m }\end{array}$} & \multicolumn{6}{|c|}{ 単位量 $\mathrm{kg} / \mathrm{m}^{3}$} \\
\hline & & & \multirow{2}{*}{$\begin{array}{l}\text { セx } \\
\text { ント }\end{array}$} & \multirow{2}{*}{ 水 } & \multirow{2}{*}{ 細骨材 } & \multirow{2}{*}{ 粗骨材 } & \multicolumn{2}{|c|}{ 混和剤 } \\
\hline & & & & & & & 夏期 & 冬期 \\
\hline 21 & \multirow{4}{*}{2.0} & 60 (行) & 833 & 175 & 501 & 898 & 28.3 & 20.8 \\
\hline 30 & & 55 (7n-) & 583 & 175 & 710 & 898 & 11.7 & 6.4 \\
\hline 40 & & $22($ スランプ $)$ & 438 & 175 & 796 & 930 & 7.4 & 3.3 \\
\hline 45 & & $21($ スランク゚ $)$ & 389 & 175 & 838 & 930 . & 6.6 & 2.5 \\
\hline
\end{tabular}
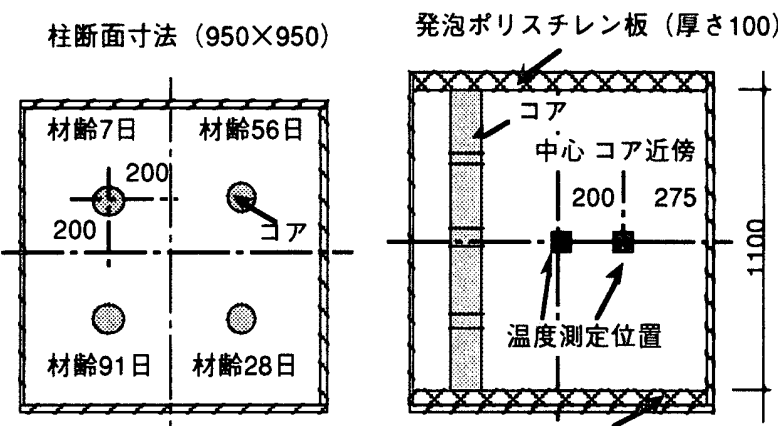

$$
\text { 平面立断面 }
$$

図10 柱構造体モデル

表 7 フレッシュコンクリートの性状

\begin{tabular}{|c|c|c|c|c|c|c|c|c|}
\hline & \multirow{2}{*}{$\begin{array}{c}\text { W/C } \\
\%\end{array}$} & \multicolumn{2}{|c|}{ 練混ぜ時間 } & \multirow{2}{*}{$\begin{array}{c}\text { 空気 } \\
\text { 量 } \\
\%\end{array}$} & \multirow{2}{*}{$\begin{array}{c}27 \% 7^{\circ} \text { 吅 } \\
\mathrm{c} \mathrm{m}\end{array}$} & \multirow{2}{*}{$\begin{array}{c}\text { בン夘- } \\
\text { 温度 } \\
{ }^{\circ} \mathrm{C}\end{array}$} & \multirow{2}{*}{$\begin{array}{c}\text { 推定 } \\
\text { W/C } \\
\%\end{array}$} & \multirow{2}{*}{$\begin{array}{c}\text { 柱最高 } \\
\text { 温度 } \\
{ }^{\circ} \mathrm{C}\end{array}$} \\
\hline & & $\begin{array}{c}\text { 现外 } \\
\text { 秒 }\end{array}$ & $\begin{array}{c}\text { [ב夘- } \\
\text { 秒 }\end{array}$ & & & & & \\
\hline \multirow{4}{*}{ 夏期 } & 21 & 360 & 180 & 0.6 & 64.5 & 36.6 & 22.1 & 103 \\
\hline & 30 & 120 & 120 & 0.5 & 60.0 & 34.7 & 29.7 & 91.3 \\
\hline & 40 & - & 60 & 1.2 & $21.0($ スランプ $)$ & 34.4 & 40.2 & 80.3 \\
\hline & 45 & - & 60 & 1.0 & $22.0($ スランプ $)$ & 33.7 & 45.8 & 74.5 \\
\hline \multirow{4}{*}{ 冬期 } & 21 & 900 & 120 & 2.8 & 53.5 & 15.6 & 22.3 & 76.0 \\
\hline & 30 & 120 & 120 & 1.2 & 58.0 & 13.0 & 30.5 & 68.3 \\
\hline & 40 & - & 60 & 2.0 & $22.0\left(85: 7^{\circ}\right)$ & 10.9 & 40.9 & 50.6 \\
\hline & 45 & - & 60 & 3.2 & $22.0($ スラフフ $)$ & 10.6 & 45.0 & 44.7 \\
\hline
\end{tabular}


が重要な要因となるため、練混ぜたフレッシュコンクリートの単位 水量を水中質量法 ${ }^{12}$ によって測定し、コンクリート中の実際の単 位水量を確認することとした。

\subsection{3練混ぜ}

練混ぜは容量 $3 \mathrm{~m}^{3}$ の水平二軸式ミキサを用いて行った。練混ぜ 量は $1.5 \mathrm{~m}^{3}$ とした。水セメント比 $21 \%$ おる゙ $30 \%$ のコンクリトに ついては、ミキサへの負荷を考慮し、モルタル先練り方式で練り混 ぜた。

\subsection{4 柱構造体モデル}

作製した柱構造体モデルを図10に示す。柱構造体モデルは、断 面 $950 \times 950 \mathrm{~mm}$ 、高さ $1100 \mathrm{~mm}$ の実大寸法とし、上下を発泡ポリス チレンで断熱することで、部材内の温度条件を実際の柱部材に近い ものとした。コア供試体は所定の材齢で図に示す位置から採取した。

\section{3 実験結果}

3.3.1 フレッシュコンクリートの性状

コンクリートの練混ぜ時間および練り上がり性状を表 7 に示す。

各調合とも、概ね目標とした性状となった。水中質量法によって求 めた各調合の推定水セメント比も、概ね目標值程度を示した。

\subsection{2 柱構造体モデルの温度履歴}

柱構造体モデルの温度履歴を図11に示す。いずれの調合も、柱 構造体モデルの中心では、夏期と冬期に $20^{\circ} \mathrm{C}$ 以上の温度差がみら れた。また、いずれの調合でも、コア供試体採取位置と中心部の最 高温度の差は $3{ }^{\circ} \mathrm{C}$ 以内であった。

\subsection{3 強度発現性状}

材齢と圧縮強度の関係を図 12 に示す。コア供試体と標準養生し た供試体の強度発現性状を比較すると、コア供試体は、材齢 7 日で は高い压縮強度を発現するものの、材齢 7 日以降の圧縮強度の增加 は緩慢になることがわかる。一方、標準養生した供試体は、材齢 7 日では低い圧縮強度となるものの、材齢 7 日以降の圧縮強度の増加 は大きいことがわかる。また冬期であれば、水セメント比 $40 \%$ と $45 \%$ に、養生条件の違いによる材齢 28 日以降の圧縮強度の差は ほとんどないことがわかる。

材齢91日におけるセメント水比と強度比 R の関係を図13に示す。 ここで、図中の水セメント比の值は実測した単位水量測定の結果を 反映させている。これより、冬期に比べて夏期に強度比 $\mathrm{R}$ が小さく なるのは水セメント比30 45\%の範囲であり、水セメント比 $21 \%$ では逆の傾向となることがわかる。この結果はセメントペーストを 用いた室内実験と同様の傾向を示している。また強度比 $\mathrm{R}$ は、冬期 の場合には水七メント比の低い $21 \%$ お よび $30 \%$ ばは.9程度となり、 水セメント比の高い $40 \%$ および $45 \%$ では 1.0 を上回るという傾向に あるが、夏期の場合には水セメント比 $40 \%$ 程度で最も低い 0.7 程度 となることがわかる。

材龄91日における初期温度履歴の最高温度と強度比 $\mathrm{R}$ の関係を 図14に示す。図中にはセメントペーストを用いた室内実験の結果 もあわせて示した。これより、強度比 $\mathrm{R}$ は水セメント比 $30 \sim 45 \%$ の範囲では初期温度履歴の最高温度が高くなるほど小さくなるが、 水セメント比 $20 \%$ 程度では初期温度履歴の影響をあまり受けない ことがわかる。また、セメントペースト実験より求めた強度比 Rと 比較し、実大実験で求めたコンクリートの強度比 $\mathrm{R}$ は同じような傾 向を示すものの、明確な相関は得られなかった。

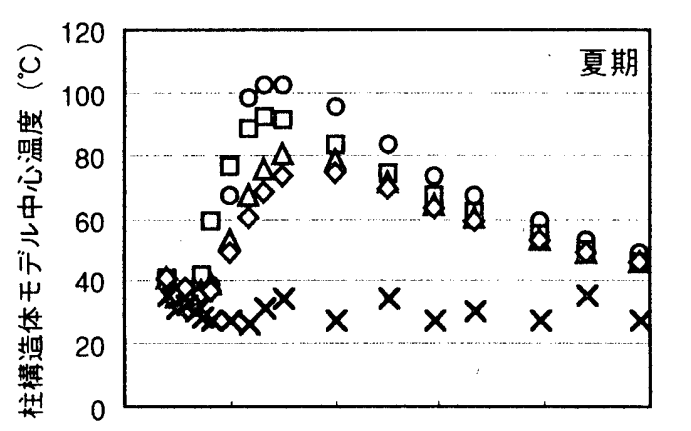

$\mathrm{OW} / \mathrm{C}=21 \%$ D $W / C=30 \%$ $\triangle W / C=40 \%$ $\Delta W / C=45 \%$ X外気

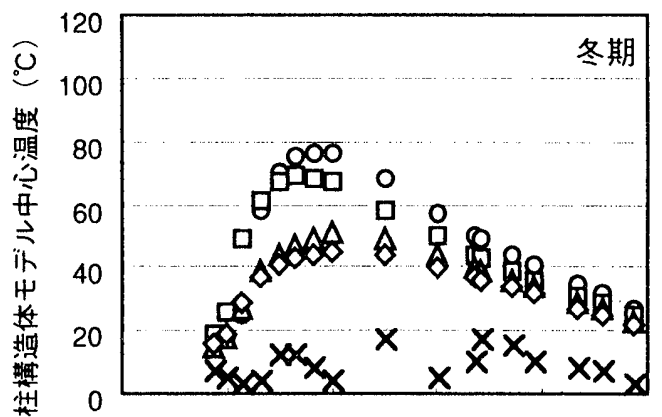

$\mathrm{OW} / \mathrm{C}=21 \%$ $\square \mathrm{W} / \mathrm{C}=30 \%$ $\triangle W / C=40 \%$ $\checkmark W / C=45 \%$ $\mathrm{X}$ 外気 O時 0 分 0 時 0 分 0 時 0 分 0 時 0 分 0 時 0 分 0 時 0 分 図11 柱構造体モデル中心の温度履歴
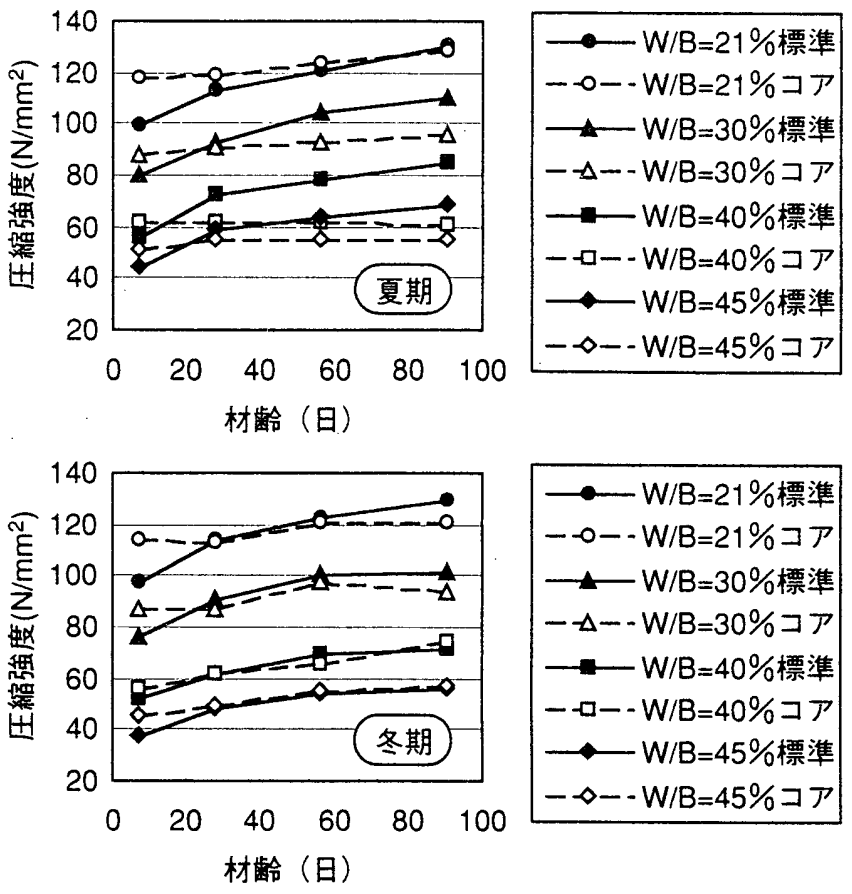

図12 材齢と圧縮強度の関係

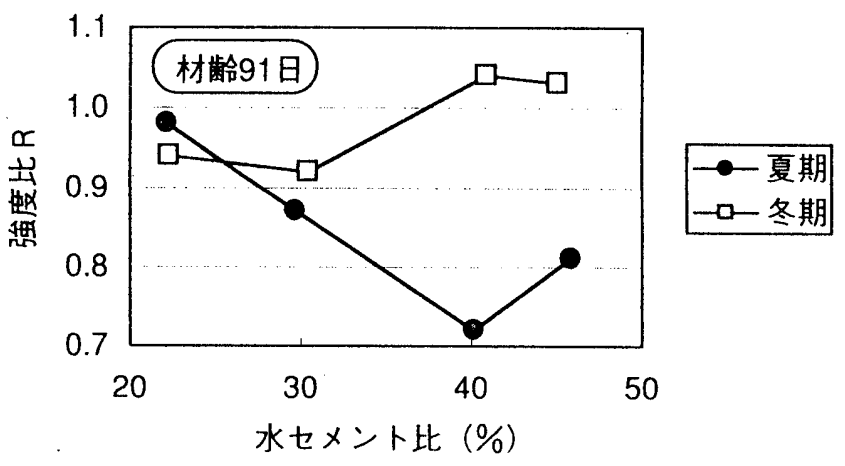

図13材踰91日におけるセメント水比と強度比 R の関係 


\section{4.まとめ}

初期温度履歴の最高温度が低水セメント比のセメント硬化体の強 度発現性状および微細構造に与える影響を検討し、以下の結論を得 た。

（1）初期に高い温度履歴を受けたセメントペーストの圧縮強度は、 初期材龄では標準養生したものよりも高い強度を発現するも のの、その後の水和が停滞し、ある材制を経過すると標準養 生したものよりも低くなる傾向があることが再確認できた。 また、水セメント比が $40 \%$ の場合には、初期により高い温度 履歴を受けたセメントペーストほど標準養生したものよりも 材齢91日圧縮強度が低くなる傾向が見られたが、水セメント 比が低くなるにつれてその差は小さくなる傾向にあった。

（2）材耣91日における水セメント比 $30 \%$ および $40 \%$ のセメント ペーストでは、初期温度履歴の最高温度が高くなるほど強熱 減量が小さく、総細孔容積も大きくなる。このことは、（1） の結果とよく符合する。

（3）水セメント比 $20 \%$ のメントペーストでは、圧縮強度、強熱 減量および総細孔容積に対する初期温度履歷の影響が小さい。 これは、水セメント比 $30 \%$ や $40 \%$ のものに比べて卓越する細 孔径が小さく、その容積も小さいことから、標準養生した場 合でも水和が進行しにくいことが原因と考えられる。

（4）コンクリートの強度比 Rは、水セメント比 $30 \%$ 45\%の範囲 では初期温度履歴の最高温度が高くなるほど小さくなるが、 水セメント比 $21 \%$ ば初期温度履歴の影響を受けにくく、い ずれの温度条件であっても0.9を超え、1.0に近い值となる。 これらの傾向はセメントペーストの実験結果と同様である。 ただし、セメントペースト実験で求めた強度比 R からコンク リートの強度比 Rを推定するには、更なる検討を必要とする。

本論では、セメント硬化体の強度発現のメカニズムを微細構造 という物理的な観点から明らかにした。今後は、文献8）などで扱 われている化学的な性質（養生温度による水和物の違い）なども 含めて検討を進めたい。

\section{参考文献}

1）飯島猉人·户祭邦之·黒羽健嗣：設計基準強度 $600 \mathrm{~kg} / \mathrm{cm}^{2}$ を目標とした構造 体強度の検討,日本建築学会大会学術講演梗概集,pp.545 546,1989.10

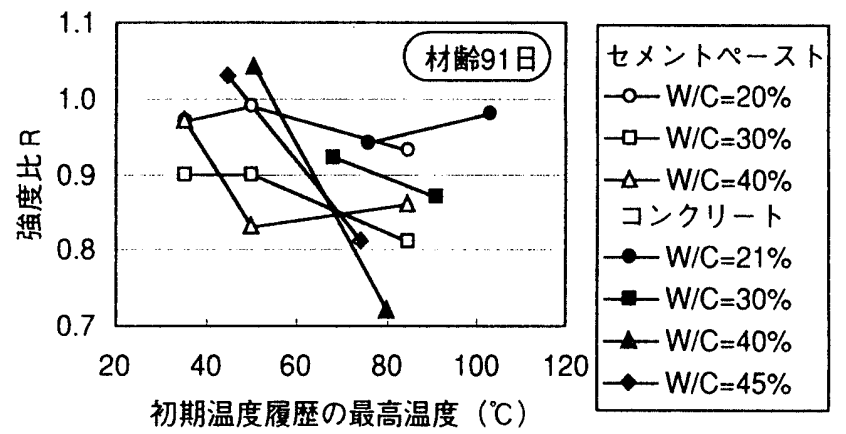

図14＼cjkstart材龄91日における初期温度履歴の最高温度と 強度比 $\mathrm{R}$ の関係

2）丸鴄紀夫·戸祭邦之·黑羽健嗣：高強度コンクリートの水和発熱による温度 上昇がセメントの水和と強度発現に及ほす影櫭,コンクリート工学年次論 文報告集,Vol.14,No.1,pp. 457 462,1992

3）地濃茂雄・仕入豊和：コンクリートの強度発現性状におよはす温度履歴条 件 $\left(20 \sim 90^{\circ} \mathrm{C}\right)$ の影響, 日本建 築学会論文報告集,NO.337,pp. 8 14, 1984.3

4）杉山 央·桝田佳寛：初期高温を受けたコンクリートの長期強度発現性, 日 本建築学会構造系論文報告集,NO.515,pp. 23 30,1999. 1

5）橋田 浩·黑田泰弘・山猗庸行：CEB-FIPモデルを改良した高強度コンクリ 一ト構造部材の力学特性発現モデル,日本建築学会構造系諭文報告 集,NO.513,pp. 9 14, 1998. 11

6）丸嶋紀夫·黒羽健嗣·戸祭邦之：水セメント比の異なるセメントペーストの 水和反応と強度発現,日本建 築学会大会学術講演梗概集,pp.1 2,1994.9

7）三井健郎·小島正朗・米澤敏男：初期材齢での高温養生条件における超高強 度コンクリートの強度発現に及ほす骨材品質の影響, コンクリート工学年 次論文報告集,Vol.17,No.1,ppl 025 1030, 1995

8）坂部 大·名和豊春・田中洋一・大久保正弘：初期高温盖生したセメント硬 化体の強度発現性と微細構造に関する研究,コンクリート工学年次論 文報 告集、Vol.18, No.1,pp. 501 506,1996

9）野口貴文·橋田 浩·能町 宏·友澤史紀：高強度コンクリート構造物の強 度発現性と組織構造の経時変化, 日本建築学会大会学術講演梗概集,pp. 15 $\sim 16,1999.9$

10）後藤孝治·魚本健人：ポルトランドセメントペースト硬化体の強度発現機 構に関する研究, コンクリート工学論文集,Vol.5,No.1,pp.109 117,1994.1

11）森本丈太郎·魚本健人：初期高温養生したポルトランドセメントの細孔構 造に関する研究, コンクリート工学論文集,Vol.7,No.1,pp.153 159,1996.1

12）丸嶋紀夫·黒羽健嗣·並木 哲·久保田浩：水中質量法によるフレッシュ コンクリートの単位水量試験方法,コンクリート工学年次論文報告 集,Vol.20, No.2,pp. 313 318,1998 